\title{
CIRCULATION AT THE TOP: ELITES, SOCIAL MOBILITY AND INTERGENERATIONAL CAPITAL CONVERSION
}

\section{CIRCULAÇÃO NO TOPO: ELITES, MOBILIDADE SOCIAL E CONVERSÃO INTERGERACIONAL DE CAPITAL}

Johs Hjellbrekke*

Olav Korsnes**

Introduction

Since Pareto's seminal work (PARETO, 1901), the sociology of social class and the sociology of elites have traditionally stood in opposition to each other. The founding fathers of the Italian school of elite sociology were all critical of Marxist thought, and its focus on class conflicts as the main cause of social change (HARTMANN, 2007). That they also were skeptical towards modern democracy, and that a leading theorist like Robert Michels towards the end of his life was affiliated with the Italian fascist movement, added to the division. Despite calls for bridging the gap between the sociology of social class and the sociology of elites (ARON, 1950 a, b; SCOTT, 1996), mutual skepticism and also negligence has therefore been more dominating than attempts at combining elements from the two approaches. Insights and approaches that could have cross-fertilized the two traditions have therefore had difficulties when travelling from the one to the other.

Despite clear theoretical and political differences, this is in many ways paradoxical. Even though Pareto was one of the first to focus on social mobility as the inter- and intra-generational circulation of elite groupings, most studies of social mobility have almost exclusively focused on class mobility (ERIKSON \& GOLDTHORPE, 1992). Vice versa, important methodological innovations in mobility studies, as for instance log-linear modeling of mobility tables, have not found its way into studies of circulation mobility in the elites. In one sense, the situation can

\footnotetext{
* Professor of Sociology at the University of Bergen (Bergen/Noruega). E-mail: Johs.Hjellbrekke@uib.no

** Professor Emeritus at the University of Bergen (Bergen/Noruega). E-mail: Olav.Korsnes@uib.no
} 
therefore be described as one characterized by "splendid isolation" and of mutual misrecognition. In this article, we shall attempt to bridge parts of this gap by applying approaches and statistical techniques commonly used in studies of class mobility in an analysis of circulation mobility in elite formations. In this way, we'll argue, new insights into the stability and change of intergenerational elite reproduction and circulation can be gained.

Focusing on patterns of intergenerational reproduction, we shall present an analysis of the internal and intergenerational circulation at the top of the Norwegian educational and professional hierarchies. The analyses are done on register data on the whole Norwegian population born 1955-1975. Data stem from multiple merged data registers. All individuals with a Norwegian social security number are included in the data set. The quality of the data set is generally (and internationally) regarded as exceptionally high.

In the analysis of intergenerational educational mobility, we restrict ourselves to an analysis of all Norwegians born 1955-1975 whose fathers have completed the longest higher educations, and who themselves have not experienced downward educational mobility. The offspring's education was registered in 2008, when the youngest children were 33 years old. At this age, the overall majority had finished their educations. With these restrictions applied, we focus in on 1.3\% of the cohort population. While these children have succeeded in reproducing their fathers' educational levels, they might even so have educations from other disciplines.

Thereafter, following a similar strategy, we shall analyze the professional mobility barriers and trajectories of the children whose fathers were CEOs or worked in a free or a "learned profession" in 1980, and who themselves have ended up in similar positions approximately 25 years later (in the years 2003-2008). This group of inheritors constitute $0.6 \%$ of the total Norwegian cohort population. In combination, a substantial proportion of the Norwegian elites is recruited from these two subgroups of inheritors within the educational and professional population. ${ }^{1}$

Because intergenerational family networks also are key components in dynasties, an analysis of these two forms of mobility can give us good indications on dynasty formations in the Norwegian elites. Family relations like these can also be valuable forms of social capital, a form of capital that may both facilitate the conversion of one form of capital into another, and elevate networkbased resource mobilization (DENORD et. al., 2011). Furthermore, the analysis of mobility barriers and trajectories will indirectly also give information on intergenerational strategies for capital conversion. If capital assets linked to specific educations or professions, e.g. the medical profession, isn't or cannot be reproduced, the inherited or embodied cultural capital can nevertheless be converted into other specific forms of institutionalized cultural capital, e.g. from a medical degree to a law degree. Put differently, whereas the volume of institutional-

1. See Hjellbrekke et al. 2007 and Denord et al. 2011, based on data from the Norwegian Power and Democracy Survey on Norwegian elites (Gulbrandsen \& al. 2002 ) for further details. According to the survey, $62 \%$ of the elite position holders had a higher university degree or an education at PhD level, while only $2.6 \%$ finished their education after compulsory education. 
ized cultural capital can be reproduced from one generation to the next, the specific type of the same capital may even so be different, as will also its respective field value.

Against this background, we address the following research questions: What forms of intergenerational capital conversion have been the most common, and therefore also the most acceptable, in the upper and upper middle classes in postwar Norway? And what conversions have been less common? Rephrasing Max Weber's classic formulation: Can we identify a cluster of elite situations between which mobility has been both easy and typical (WEBER, 1978)? Are there clear indications of social closure, also for the ones with a social origin at the top of the social hierarchy, or are these "elite" mobility structures rather open? How are the patterns structured? What have been the typical mobility barriers and mobility trajectories between the positions at the top? Can we find clear trends, either of stability or in the direction of increasing or decreasing circulation? And what can patterns like these tell us about the status hierarchies internally in what Pierre Bourdieu (BOURDIEU, 1989; BOURDIEU \& SAINT MARTIN, 1978) conceptualized as a "field of power"? Is it for instance possible to identify a hierarchy of professions, in that some positions and educations seem more attractive than others? And perhaps even more important: between what positions are the family dynastic relations, and thus also the relations of inherited cultural and social capital, the strongest?

\section{Norwegian Egalitarianism}

Social mobility occurs in different societal contexts and in different societal hierarchies. The recruitment to top positions varies between states (ARON, 1950 a, b; HARTMANN, 2006), and so does also perceptions of how clear the societal hierarchies actually are. Norwegian respondents tend to view their society in far more egalitarian terms than respondents in other countries, including neighboring Sweden (HJELLBREKKE \& KORSNES, 2012). When compared to countries in Europe and in North and South America, the differences become very clear:

Table 1: Variations of Societal Perceptions. "Type of Society My Country Is" by "Country". Data from ISSP 2009. Social Inequality IV

\begin{tabular}{|c|c|c|c|c|c|}
\hline & Country & & & & \\
\hline Type of Society My Country Is & Norway & GB/UK & France & Argentina & USA \\
\hline $\begin{array}{l}\text { An elite at the top, few in the middle, } \\
\text { many at the bottom }\end{array}$ & 2.1 & 14.9 & 16.4 & 45.6 & 17.2 \\
\hline $\begin{array}{l}\text { A society that looks like a pyramid, } \\
\text { with an elite at the top, more in the } \\
\text { middle, and most at the bottom }\end{array}$ & 10.8 & 41.9 & 53.6 & 36.1 & 38.9 \\
\hline $\begin{array}{l}\text { A pyramid, but with few people at the } \\
\text { bottom }\end{array}$ & 23.6 & 18.9 & 16.3 & 9.4 & 15.0 \\
\hline $\begin{array}{l}\text { A society where most people are in the } \\
\text { middle }\end{array}$ & 56.4 & 20.9 & 12.1 & 7.0 & 26.0 \\
\hline $\begin{array}{l}\text { Many people at the top, only very few } \\
\text { at the bottom }\end{array}$ & 7.1 & 2.5 & 1.6 & 1.9 & 2.9 \\
\hline Total & 100 & 100 & 100 & 100 & 100 \\
\hline
\end{tabular}


Whereas a majority in the other countries in Table 1 perceive their societies as hierarchically organized, the opposite is the case for Norway. Perceptions like these do not readily go together with the existence of distinct elite formations, characterized by a high degree of social reproduction from one generation to the next, and with high levels of marital homogamy. In fact, both the existence and the legitimacy of elites will easily be considered as more problematic in a country where the degree of social inequality is comparatively low. But does this imply that these elites do not exist, that the tendencies towards social reproduction and social closure are low, and that dynastic elements are hard to identify? As our analysis will demonstrate, this is hardly the case, but it may reflect the legacy of what the Norwegian historian Francis Sejersted described as the historical "Sonderweg" of Norwegian modernity (SEJERSTED, 1993).

Compared to the situation in neighboring Sweden, for instance, the Norwegian elites were weak, and therefore also played a less dominant role in the modernization processes. Unlike in Sweden and Denmark, the Norwegian nobility was abolished in 1821. The political power of the higher civil servants would soon be challenged by a coalition of farmers and urban bourgeois liberals. Furthermore, the industrial and financial bourgeoisie was not in a position to finance large-scale industrial investments. As Sejersted (op.cit.) pointed out, the Norwegian state would therefore have to play a compensatory role; it stepped in as an agent where capitalist groups otherwise would have taken the lead. Somewhat simplified, the Norwe- gian elites lacked both the economic and cultural capital bases that were found in other countries, e.g. France and Sweden (PIKETTY, 2019). The formation of elite dynasties might therefore have been more difficult in Norway, resulting in less stable elite formations than in other countries.

\section{Elites and professions}

It is not only the analytical relation between elites and classes that has been contested. The same is the case for the elite concept itself. Who is, and who is not a part of the elite in a given society? Pareto would alternate between a conceptualization of the upper classes as an elite or as an aristocracy, and also of the elites as a class in itself. Internally, the elites were also divided into governing and non-governing elites (PARETO, 1935). The recruitment to these elites was socially skewed, but Pareto emphasized the continuous, and sometimes rapid changing of the governing elites, i.e. elite circulation (KOLABINSKA, 1912). Members of the non-governing elite would topple the governing elite, and members of other classes would also enter the nongoverning elites. The study of elites was therefore also a study of social mobility between, from and into the elites.

Others have sought to identify the elites by focusing on those in leading positions in a set of sectors, e.g. the military, in politics, higher civil service, the church, in research, culture, business etc. (ARON, 1950a, b). If identified like this, many of those included in the elites will have a higher education, and in many cases also belong to a profession. Using Andrew Abbotts rather wide

2. i.e. the "special way" in which Norway went from being a traditional society to becoming an industrial, capitalist society. 
definition, a profession can be understood as an exclusive occupational group that applies abstract knowledge on a specific case (ABBOTT, 1988). The group succeeds in claiming an occupational monopoly, where only those with the licensed abstract knowledge have the jurisdiction to practice. In most cases, this necessitates a higher education from a higher educational institution. In Abbott's system approach, where ongoing struggles about the borders for professional power is regarded a key element, the hierarchy of professions has three levels: free professions, subordinate professions and "would be"-professions.

The recruitment to the elites will in most cases be much stronger from the first of these three levels. For this reason, and based on the results found in Hjellbrekke et al. 2007 and Denord et al. 2011, even though having a higher education or being a member of a free profession not in itself guarantees membership in the elites of a given society, our analysis builds on two well-documented empirical presuppositions:

- Elites are disproportionally recruited from those with the highest educations and from those that are members of the highest levels of the profession and occupation hierarchy

- Internally in these two group formations, elites are more often recruited among those who have inherited their educational level and/or their professional category. As this indicates, a distinct core of inheritors can be identified in each of the elite group formations.

In order to examine these "structures of inheritance" in greater detail, in the analysis of educational reproduction and circulation, we restrict ourselves only to include persons with the very longest, higher educations, i.e. master degree and above. While some of these, like medicine and law, clearly belong to the professions, this is less obvious for educations in languages, history, sociology etc. Furthermore, we also restrict the sample so that only the intergenerational circulation between a subset of positions, most of them belonging to the highest of Abbott's three levels or to higher positions in business, is included. With this approach, we seek to identify a core of "circulating inheritors" at the top of these two hierarchies; the educational and the professional hierarchies.

\section{Circulation Mobility and Conversion Strategies}

Even though Kolabinska (1912) and Pareto (1901) were the first to address the problem of circulation mobility, the overall majority of sociological studies have found more inspiration in Pitirim Sorokin's work on social mobility in general (Sorokin, 1927, 1933). The research questions have mainly focused on whether or not one can identify distinct mobility regimes in given types of societies, and whether or not clear trends towards increasing or decreasing mobility can be found. The results have depended both on the available data and on the methods.

Whereas Sorokin (1927) in his analysis of a wide range of historical sources concluded that no clear trends could be identified across time and space, Lipset $\&$ Zetterberg (1956) claimed that the mobility regimes in modern industrial societies basically were the same. The Lipset-Zetterberg hypothesis has since been modified several times. Featherman, Jones and Hauser (1975) concluded that the patterns of circulation were the same in all countries where market economy and the nucleus family are key institutions. But the level 
or the strength of the circulation still varied. Erikson \& Goldthorpe (1992) modified this thesis yet again, and claimed that the relative mobility, i.e. the level of mobility that not can be ascribed to macro structural changes e.g. in the labor market, showed a high degree of temporal stability. There were thus limits to circulation.

Breen Et al. (2004) would revise several of these results. Whereas some countries are characterized by a relatively high degree of stability, others are more open. The variation with respect to how open they actually are, is also substantial. Finally, in their analyses of microclass reproduction and micro-class mobility, both Grusky \&t Weeden (2001) and Jonsson \&t al (2009) find a considerable level of occupational reproduction. What at first might seem as class reproduction is actually strongly linked to the direct inter-generational reproduction in occupations. Important Norwegian studies from the 1950s and 60s on the recruitment to higher civil service and to the professions, came to similar conclusions (AUBERT, 1960; AUBERT et. al., 1960).

Unfortunately, even though the problem of reproduction of, and mobility into the elites has been a classic theme at least since Plato's "Republic", few of the above mentioned studies have been important sources of inspiration for the sociology of elites. Even so, also in the sociology of elites, a high degree of mobility has been regarded as positive, both because it has legitimized a democratic political system, and because it has been seen as a way to maximize a society's human resources. But some researchers have voiced their reservations. In 2008, John Higley (2008, 16) argued that a high rate of intergenerational mobility into the elites could lead to problems. If the "inheritance right" became too weak, the elites could loose their motivation and their interest for entering the top positions, and the existence of "consensually unified elites", or an "enlightened oligarchy", be threatened (FIELD \& HIGLEY, 1980; HIGLEY, 2008). Without going into a polemic against Higley's hypotheses and the assumptions they build on: where is this "right to inheritance" at its strongest in the Norwegian case? And are there clear trends of intergenerational circulation between the positions at the top of the hierarchy? If so: what does this tell us about stability and change in elite circulation in the assumed egalitarian Norwegian society?

\section{Absolute and relative mobility rates}

To identify these patterns, it is necessary to analyze both the absolute and the relative mobility rates. Briefly explained, absolute mobility rates reveal the percentages or proportions of children who have either remained in the same positions as their parents, i.e. have been immobile, or who have moved either upwards, sideways or downwards in a given hierarchy. The relative mobility rates describe the odds children in one position have to end up in a given position as compared to those of children in other positions. The relative mobility rates can thus be expressed as the ratio of two odds, i.e. the odds ratio.

Whereas the outflow percentages tell us what destination category the children of a given origin category have moved into, the inflow percentages reveal the origin composition of a given destination category. This is necessary information if we want to assess the size of the group of inheritors, e.g. in the medical profession, or if we want to identify the typical and atypical intergenerational movements in the mobility structures. 
But if we restrict ourselves only to examining these patterns, we can easily come to wrong conclusions about the relative stability between $\mathrm{t} 1$ and $\mathrm{t} 2$. Macro-structural changes, e.g. in occupational structures, will "force" some children to find other jobs than their parents, simply because there are too few destination categories for the offspring. A typical example is in agriculture, where the number of farmers has steadily fallen from decade to decade. For many farmers' children, there was no longer an empty position that could be filled when they entered the labor market. The same is the case for the textile and the steel industry in Europe. In consequence, these children were "forced" into occupational social mobility.

In mobility research, it has therefore been common also to analyze the relative mobility patterns by way of log-linear modelling (EYE \& MUN, 2013). The relative mobility is the part of the mobility that is not caused by macro-structural changes. Depending on how they are specified, loglinear models can reveal whether or not there is a statistical association between the origin and the destination categories independently of such macro-structural changes. If there is an association, what type of association is it? Is the association stable or does it change over time in a given direction? Are the chances for mobility the same at all the levels in the hierarchy? If they change, do they change in the same directions for all the levels in the hierarchy? By analyzing the patterns in the odds ratios, these questions can be answered.

\section{Intergenerational Educational Mobility at the Top}

As in most other modern societies, also in Norway, entering higher studies was a privilege for the few. In 1950, with a total population of 3 million people, there were only 6000 registered students in the higher educational institutions. Not surprisingly, the recruitment was also socially skewed. In the academic professions, the children of academics, private businessmen and higher civil servants were strongly overrepresented. Children of farmers, workers and lower middle class occupations would instead orient themselves towards educations in science or engineering (LINDBEKK, 1962). The two latter educations have also had a higher rate of downward social mobility (CHRISTOPHERSEN, 2011). Put differently, the more "democratized" the recruitment to a given higher education has been, the lower the intergenerational reproduction. Newer studies have confirmed the continuity of the trends first revealed in the 1950s and 1960s (Hansen, 1999, 2000). The recruitment to elite educations is still strongly skewed. So are the examination results, and the prospects for converting institutionalized cultural capital into economic capital (HANSEN, 2001). The higher the social origin, the better are the average grades and the higher the average salary a few years down the road.

As shown by Flemmen (2012), and by way of multiple correspondence analysis (see HJELLBREKKE, 2018), the Norwegian upper class is internally structured along two main dimensions. The first separates between high and low volumes of inherited capital and high and low volumes of educational capital. The second separates between proprietors and higher employees. In a groundbreaking recent study, Toft (2018a) has analyzed the intra-generational mobility careers within this space. By way of sequence analysis (CORNWELL, 2016), a clear opposition between the economic and the cultural capital 
fraction is revealed. Whereas intra-generational vertical mobility is rather common, intra-generational horizontal mobility is not. Movements are therefore more typically sector-internal than cross-sectorial. Intergenerational movements within and into the upper class is furthermore polarized by an opposition between inheritors and newcomers, and by an opposition between the economic inheritors and the others (TOFT, 2018b). In this way, the results from Toft's recent analyses of the upper classes are similar to the results found by Hjellbrekke \&t Korsnes (2005) and Hjellbrekke \&t al. (2007) in their analyses of the elites, where a triangular structure, with one cultural, one political and one economic pole is revealed. In each of these, we find a core of inheritors. Inter-sectorial circulation is less common, but is facilitated by high volumes of political capital. None of the above mentioned studies have sought to analyze the relative mobility. Little is therefore known about the elite-internal inter-cohort stability in the circulation mobility. Have these structures changed over time, and if so, in what direction?

When we focus in on the inheritors at the top of the educational capital hierarchy, i.e. a high-volume capital group within the Norwegian upper class, the patterns in the absolute mobility are clear:

Table 2: Father's higher education when child was 16 yrs old vs. Child's higher education in 2008. Children born 1955-1974. Outflow percentages

\begin{tabular}{|c|c|c|c|c|c|c|c|c|}
\hline Father's & & & Child's Hig & her E & ation 20 & & & \\
\hline $\begin{array}{l}\text { higher } \\
\text { education } \\
\text { when child } \\
\text { was } 16 \text { yrs } \\
\text { old. }\end{array}$ & $\begin{array}{l}\text { Humani- } \\
\text { ties }\end{array}$ & $\begin{array}{l}\text { Social } \\
\text { Sciences }\end{array}$ & $\begin{array}{l}\text { Psycho- } \\
\text { logy }\end{array}$ & Law & $\begin{array}{l}\text { Econo- } \\
\text { mics }\end{array}$ & $\begin{array}{l}\text { Sciences } \\
\text { Enginee- } \\
\text { ring }\end{array}$ & $\begin{array}{l}\text { Medicine } \\
\text { Odonto- } \\
\text { logy }\end{array}$ & Total \\
\hline $\begin{array}{l}\text { Humani- } \\
\text { ties }\end{array}$ & 30.3 & 10.2 & 4.0 & 12.3 & 7.1 & 22.6 & 13.5 & 100 \\
\hline $\begin{array}{l}\text { Social } \\
\text { Sciences }\end{array}$ & 16.1 & 18.2 & 4.9 & 15.8 & 11.2 & 24.9 & 8.8 & 100 \\
\hline $\begin{array}{l}\text { Psycho- } \\
\text { logy }\end{array}$ & 14.8 & 10.7 & 21.0 & 12.4 & 8.6 & 20.7 & 11.7 & 100 \\
\hline Law & 9.8 & 6.0 & 2.0 & 46.7 & 6.3 & 20.8 & 8.4 & 100 \\
\hline Economics & 11.2 & 9.8 & 3.3 & 16.6 & 20.8 & 30.4 & 7.9 & 100 \\
\hline $\begin{array}{l}\text { Sciences } \\
\text { Enginee- } \\
\text { ring }\end{array}$ & 9.2 & 5.8 & 2.4 & 8.4 & 8.3 & 55.4 & 10.5 & 100 \\
\hline $\begin{array}{l}\text { Medicine } \\
\text { Odonto- } \\
\text { logy }\end{array}$ & 9.6 & 5.5 & 2.9 & 11.7 & 7.1 & 30.0 & 33.5 & 100 \\
\hline Total & 12.2 & 6.7 & 3.0 & 13.8 & 8.0 & 40.1 & 16.2 & 100 \\
\hline
\end{tabular}


The direct reproduction is both strong and systematic for the educations included in Table 2. When compared to the cells in the row marginal, there are two to three times more children in the diagonal cells, where the direct reproduction is found. This strong over-representation is found in all the educations, regardless of whether or not the program has had restrictions on the intake of students. Summed up: if one first succeeds in passing the institutionalized cultural capital on to the next generation, the offspring will also have a high probability of inheriting the specific type of institutionalized cultural capital. As a consequence, a core of inheritors cannot only be identified at the top, but also across the top of this hierarchy, i.e. in each of the educational orientations.

The internal homogeneity of these educational destination categories is described in Table 3:

Table 3. Father's education when child was 16 yrs old vs. Child's education in 2008. Children born 19551974. Inflow percentages

\begin{tabular}{|c|c|c|c|c|c|c|c|c|}
\hline Father's & & & Child' & Educ & ion 2008 & & & \\
\hline $\begin{array}{l}\text { education } \\
\text { when child } \\
\text { was } 16 \text { yrs } \\
\text { old. }\end{array}$ & $\begin{array}{l}\text { Humani- } \\
\text { ties }\end{array}$ & $\begin{array}{l}\text { Social } \\
\text { Scien- } \\
\text { ces }\end{array}$ & $\begin{array}{l}\text { Psycho- } \\
\text { logy }\end{array}$ & Law & $\begin{array}{l}\text { Econo- } \\
\text { mics }\end{array}$ & $\begin{array}{l}\text { Sciences } \\
\text { Enginee- } \\
\text { ring }\end{array}$ & $\begin{array}{l}\text { Medicine } \\
\text { Odonto- } \\
\text { logy }\end{array}$ & Total \\
\hline Humanities & 30.6 & 19.0 & 16.4 & 11.0 & 10.8 & 6.9 & 10.3 & 12.3 \\
\hline $\begin{array}{l}\text { Social } \\
\text { Sciences }\end{array}$ & 2.0 & 4.1 & 2.4 & 1.7 & 2.1 & 0.9 & 0.8 & 1.5 \\
\hline Psychology & 1.8 & 2.4 & 10.5 & 1.4 & 1.6 & 0.8 & 1.1 & 1.5 \\
\hline Law & 7.9 & 8.9 & 6.6 & 33.5 & 7.7 & 5.1 & 5.1 & 9.9 \\
\hline Economics & 2.5 & 4.0 & 2.9 & 3.2 & 7.0 & 2.1 & 1.3 & 2.7 \\
\hline Sciences & 36.0 & 41.6 & 37.5 & 29.2 & 49.4 & 65.9 & 31.0 & 47.7 \\
\hline $\begin{array}{l}\text { Enginee- } \\
\text { ring }\end{array}$ & & & & & & & & \\
\hline Medicine & 19.2 & 20.0 & 23.7 & 20.0 & 21.4 & 18.2 & 50.3 & 24.3 \\
\hline Odontology & & & & & & & & \\
\hline tal & 100 & 100 & 100 & 100 & 100 & 100 & 100 & 100 \\
\hline
\end{tabular}


Two educations stand out as the most popular among these successful inheritors. "Sciences/Engineering" and "Medicine/ Odontology" sum up more of than 70\% of the children we've included in the analysis. These two are also the most homogenous destination categories with respect to social origin. 1 in 2 doctors or dentists have fathers that themselves studied medicine or odontology. In "Sciences/Engineering", this is even higher, where 2 out of 3 have inherited their fathers' educational orientation. In the humanities and in law studies, this drops to "only" 1 in 3.

Even though the barriers not in any way are water tight, there are even so clear tendencies in the movements described in tables 1 and 2. Movements between Medicine/Odontology and Sciences/ Engineering are relatively common, as are movements between Psychology, Social Sciences and Humanities. While the internal exchange in these two clusters is relatively high, the exchange between these two, as measured by the outflow percentages, is lower than what could be expected. As shown by the inflow percentages, Law recruits rather broadly, but children with family backgrounds in Sciences/Engineering are underrepresented. Based on the distributions in Tables 1 and 2, we can thus identify three gravitational centers in this subspace of educational inheritors. One the one side, we find Humanities, Social Sciences and Psychology, and on the other, Sciences/Engineering and Medicine/Odontology. Law is in an intermediate position.
Because of institutional changes, the children in the oldest and the youngest cohorts have taken their educations in two different educational systems. The strong increase in the number of students and of positions at top of the educational hierarchy, also implies an educational inflation. The status of a given education can therefore be much changed from t1 to t2. And while it might have become easier to become an "inheritor", simply because a higher percentage of children have taken higher education, this might also result in increasing mobility and an increasing competition for the most coveted positions from children of lowly educated parents. This, in turn, might have had an impact on the intergenerational circulation and thus also on the conversion of institutionalized cultural capital from one generation to the next. Previous analyses have found that on a societal level, the pattern even so is one of relative stability (HJELLBREKKE \& KORSNES, 2012). Throughout a period of educational expansion, the association between the educational origin and the educational destination remained highly stable. But is it the same for those who have remained at the top?

Following Louis André Vallet's analytical strategy for analyzing social mobility in postwar France (VALLET, 1999), we have done a series of log-linear analyses of the cohorts born 1955-59, 1960-64, 1965-69 and 1970-74 to model stability and change. The results show that it is the model that goes under the name of the "Constant Social Fluidity"-model that best describes the structures in the data: 


\begin{tabular}{|c|c|c|c|c|c|c|}
\hline Model & L-squared & D.f. & $\mathrm{P}$-value & Diss. Ind. & BIC & $\begin{array}{l}\text { \% expl. of } \\
\text { L-squared }\end{array}$ \\
\hline Perfect Mobility & 4368.13 & 144 & .00 & .1906 & 1690.74 & \\
\hline $\begin{array}{l}\text { Constant Social } \\
\text { Fluidity }\end{array}$ & 123 & 108 & .14 & .0280 & -940 & 97.2 \\
\hline $\begin{array}{l}\text { Uniform differences } \\
\text { in social fluidity } \\
\text { (UNIDIFF) }\end{array}$ & 120.94 & 105 & .13 & .0195 & -914.27 & 97.2 \\
\hline $\begin{array}{l}\text { Uniform differences + } \\
\text { linear trend }\end{array}$ & 122.31 & 106 & .13 & .0204 & -922.76 & 97.2 \\
\hline
\end{tabular}

This model states that the association between the row and the column variable Father's education and Own education - is the same in all the four sub-tables that we analyze. The result indicates that what we might call inter-cohort stability dominates in the relative mobility movements:

-The inheritance or reproduction patterns are the same in all the four cohorts we analyze

- The barriers against some movements are the same from one cohort to the next.

Summed up, the typical movements and barriers are therefore the same in the four birth cohorts we've analyzed. But is this also the case when it comes to occupational and professional mobility?

\section{Intergenerational Occupational Mobili- ty at the Top}

Already in 1963, Torgersen (1963) found that the recruitment to top business positions in Norway had been very stable over a period of almost 50 years. Despite the societal changes brought on by the transition from a farmer to an industrial society, the mobility into leading societal positions remained the same as around 1900. More recent international, comparative studies of social mobility have come to similar conclusions. If one corrects for the macro-structural trends, the social mobility structures prove to be stable over time (ERIKSON \& GOLDTHORPE, 1992). But is this also the case if we focus in on the occupational categories that usually are ranked in the top of the professional hierarchy?

In table 5, we zoom in on the intergenerational mobility between five positions: four classic professions - engineering, medicine, law and the religious profession - and CEOs in private business. The direct reproduction, found in the diagonal cells, turns out to vary strongly between the positions. The inheritance is lowest among the CEOs and among the priests and the higher clergy (23.2 and 23.9\% respectively), but close to, or above $60 \%$ for three of the four classic professions: 
Table 5: Father's occupational position 1980 vs. Child's occupational position 2003-2008. Outflow percentages $(\mathrm{N}=8781)$

\begin{tabular}{|c|c|c|c|c|c|c|}
\hline \multirow{3}{*}{$\begin{array}{l}\text { Father's } \\
\text { occupational } \\
\text { position in } \\
1980\end{array}$} & \multicolumn{5}{|c|}{ Child's occupational position 2003-2008. } & \multirow{3}{*}{ Total } \\
\hline & CEO & Engineering & Medicine & Law & Church & \\
\hline & $\begin{array}{l}\text { Private } \\
\text { business }\end{array}$ & & Odontology & & & \\
\hline CEO & 23.2 & 38.0 & 22.4 & 15.5 & 0.9 & 100 \\
\hline \multicolumn{7}{|l|}{$\begin{array}{l}\text { Private } \\
\text { business }\end{array}$} \\
\hline Engineering & 9.9 & 59.6 & 20.2 & 9.5 & 0.7 & 100 \\
\hline Medicine & 4.6 & 19.4 & 65.2 & 10.0 & 0.7 & 100 \\
\hline \multicolumn{7}{|l|}{ Odontology } \\
\hline Law & 7.3 & 11.7 & 18.6 & 61.5 & 0.9 & 100 \\
\hline Church & 4.0 & 19.9 & 46.0 & 6.3 & 23.9 & 100 \\
\hline Total & 13.1 & 41.9 & 30.4 & 13.4 & 1.2 & 100 \\
\hline
\end{tabular}

And while the outflow from a church origin is strong, the inflow to a church destination is weak. So far, the results therefore hint at a division into two or even three subgroups; one, where the core of direct inheritors is large, and one, where the intergenerational networks to other top positions are extensive. But numerically, the movements into the religious profession are weak.

Children with a social origin in medicine are strongly concentrated in two positions - Medicine and Engineering - i.e. two disciplines that traditionally are anchored in the experimental epistemology that dominates in the sciences. But children whose fathers held judicial, engineering and science positions are also drawn to medicine. While mobility out of the profession is limited to a select few positions, mobility into the position is more widespread. It is nearby to interpret this as an indication on the high social status enjoyed by the medical doctors. Mobility into the profession will for most children be equal to upward mobility. But mobility out of the position will often be a sign of downward mobility, even if the destination position is located at the upper levels of the prestige hierarchies.

These patterns of intergenerational mobility may also be connected with differences in access to social capital, and to seniority in the field. A strong, inherited position- or sector-internal network might give access to resources that newcomers will find hard to mobilize, and can therefore be a valuable form of social capital. High volumes of social capital will also facilitate capital conversion, and have a multiplier effect on the other forms of capital. As this indicates, social capital is at the same time an individual and a collective asset (BOURDIEU, 1986). Individuals, classes, professions and elite groupings can be ranked based on their volume, value, composition and convertibility of both personal and inherited social capital (DENORD et. al., 2011). The convertibility chances will also vary between positions. A successful CEO can convert economic capital into symbolic capital, for instance by establish a large charity trust or fund. For obvious reasons, this option will in 
most cases not be available to the average university professor or priest.

Even though we do not have data on how dense or central individual networks might be, the distributions in Table 4 are telling. In terms of family based, or inherited social capital, there are marked differences at the top. If we focus on the extent or scope of intergenerational family relations to positions outside of one's origin category, the CEOs are at the top. But if we focus on the intergenerational family relations internally in a position, the medical doctors rank highest. While the first usually also have the highest volumes of economic capital, the second traditionally rank highest in terms of social prestige, i.e. a form of symbolic capital, and of highly valued institutionalized cultural capital.

The inflow percentages are shown in Table 6:

Table 6: Father's occupational position 1980 vs. Child's occupational position 2003-2008. Inflow percentages

$\begin{array}{lllllll}\begin{array}{l}\text { Father's } \\ \text { occupational } \\ \text { position in } \\ 1980\end{array} & \begin{array}{l}\text { CEO } \\ \text { Private } \\ \text { business }\end{array} & \begin{array}{l}\text { Engineering } \\ \text { CEO }\end{array} & \begin{array}{l}\text { Medicine } \\ \text { Odontology }\end{array} & \text { Law } & \text { Church } & \text { Total } \\ \begin{array}{l}\text { Private } \\ \text { business }\end{array} & & 30.1 & 24.5 & 38.4 & 23.1 & 33.2 \\ \begin{array}{l}\text { Engineering } \\ \text { Medicine }\end{array} & 31.4 & 58.8 & 27.5 & 29.3 & 23.1 & 41.3 \\ \begin{array}{l}\text { Odontology } \\ \text { Law }\end{array} & 7.0 & 9.2 & 42.7 & 14.9 & 12.0 & 19.9 \\ \text { Church } & 2.0 & 1.0 & 2.2 & 16.6 & 2.8 & 3.6 \\ \text { Total } & 0.6 & 1.0 & 3.0 & 0.9 & 38.9 & 2.0 \\ & 100 & 100 & 100 & 100 & 100 & 100\end{array}$

As these distributions show, the relative dimensional status hierarchy in the Norsizes of the cores of inheritors vary strongly between the positions, as does also the social origin-composition. Two positions stand out as the most homogenous: CEOs in private business and Engineering/Science, where 9 out 10 have a social origin in either business or engineering families. Even though a distinct core of direct inheritors also is found in medicine, law and theology, the heterogeneity is much larger.

There are two main reasons why we find these patterns interesting. Firstly, the mobility trajectories indicate a twowegian field of power. One dimension, where educations and positions are linked to the technical-economic system, and where economic capital and educational credentials with high relevance for industry (engineering/science) are given high importance, has its highest appeal among children with the same types of educations and positions. The other dimension is more strongly linked to cultural capital (health, law, religion), and has a wider appeal to children from a broader range in the upper and upper middle classes. Along both these 
dimensions, there are clear family dynastic tendencies. But they are differently configured. The first takes the shape of interconnectedness between CEOs, engineers and persons with a science education, but the direct social reproduction is less strong (cf. Table 3). The second is centered around a strong social reproduction in two professions; medicine and law.

Secondly, these patterns indicate that there are clear differences with respect to the range of the given positions' social capital assets. The most "family-isolated" position is that of the engineers, where a narrow recruitment base into the position is combined with a selective outflow to other positions. Historically, this position was highly attractive for upwardly mobile working class children (LINDBEKK, 1962; HANSEN, 1999), but has also had a high rate of downwardly mobile children (CHRISTOPHERSEN, 2011). For the clergy, the opposite is the case. The direct reproduction rate is low, and the export to other positions high. The inflow is also rather broad. As a consequence, the family networks are more extensive. This profession was the first to be "democratized", in that it was the first that recruited more broadly, e.g. sons of farmers (MANNSÅKER, 1954).

The CEOs, the medical doctors and the lawyers combine strong intergenerational family networks and relatively broad intergenerational networks to other positions in the field. These three origin and destination positions thus combine strong position-in- ternal ties and extensive (but not necessarily weak) position-external ties. The direct reproduction is high in both Medicine and Law, but they have also a strong inflow from other positions. For the CEOs, the inflow is rather limited. But the outflow is strong. Those who remain in the position will therefore have extensive, aggregated networks to the other top positions. As a consequence, for all of these three, a strong position-internal mobilization potential is combined with a similarly strong potential for position-external resource mobilization.

But given that the number of engineers, medical doctors, lawyers and CEOs has increased sharply in the period we study, the above outlined distributions might also be affected by macro-structural changes. If we control for this overall trend; has the increase in destination positions changed the statistical association between the origin and the destination variable from cohort to cohort? If the answer is yes: in what direction? Has the mobility structure become more open or more closed?

\section{Relative professional mobility}

In order to answer these questions, we must examine the structures in the relative mobility rates. The log-linear analyses show that also in this case, the constant social fluidity model is the one that best describes the mobility trajectories in the analyzed cohorts: 
Table 7: Relative professional mobility

\begin{tabular}{|c|c|c|c|c|c|c|}
\hline Model & L-squared & D.f. & P-value & Diss. Ind. & BIC & $\begin{array}{l}\text { \% expl. of } \\
\text { L-squared }\end{array}$ \\
\hline Perfect Mobility & 3288.72 & 64 & .00 & .2072 & 1768.94 & \\
\hline Constant Social Fluidity & 42.40 & 48 & .70 & .0151 & -393.44 & 98.7 \\
\hline $\begin{array}{l}\text { Uniform differences in } \\
\text { social fluidity (UNIDIFF) }\end{array}$ & 42.14 & 45 & .62 & .0148 & -367.20 & 98.7 \\
\hline $\begin{array}{l}\text { Uniform differences + } \\
\text { linear trend }\end{array}$ & 41.71 & 46 & .65 & .0154 & -375.98 & 98.7 \\
\hline
\end{tabular}

The family dynastic networks that we lieve that the mobility barriers have been have described above are therefore stable different for daughters and sons. Furthermore, previous analyses have found that unlike men, women in the field of power can be grouped together in only three clusters; a cluster of upwardly mobile women with low global capital volumes, a cluster of "meritocrats", characterized by high educations, and a cluster of inheritors, with high volumes of inherited social capital (HJELLBREKKE \& KORSNES, 2016). In what ways might gender specific trajectories affect or change the patterns and the associations we've uncovered so far?

If we apply the same modelling strategy and separate between sons born 1955-64, 1965-74, and daughters born 1955-643 , the results turn out to be different:

3. Daughters born 1965-74 are excluded because of too many empty cells in the table. This is a known problem in log-linear modelling. 


\begin{tabular}{lcccccc}
\hline Model & L-squared & D.f. & P-value & Diss. Ind. & BIC & $\begin{array}{r}\text { \% expl. of } \\
\text { L-squared }\end{array}$ \\
Perfect Mobility & 1963.26 & 48 & .00 & .2087 & 1539.68 \\
$\begin{array}{l}\text { Constant Social Fluidity } \\
\text { Uniform differences in }\end{array}$ & 44.82 & 32 & .066 & .0212 & -237.56 & 97.7 \\
social fluidity (UNIDIFF) & 35.44 & 30 & .227 & .0172 & -229.30 & 98.2
\end{tabular}

In table 8, it's the UNIDIFF (UNIform DIFFerences)-model that best describes the mobility structures in the three tables we analyze. Under this model, we postulate that the basic patterns in the movements are the same from t1 to $t 2$, or from one table to the next, but that the intensity varies from cohort to cohort. One cohort is defined as the reference cohort, which the circulation or mobility in the other cohorts are measured against. If the association between the origin and the destination has become stronger, the relative mobility has decreased. When this is the case, the parameter value is $>1.00$. If the opposite is the case, the value is $<1.00$. In table 9 , we find both of these outcomes to be true:

Table 7: Unidiff-parameters.

\begin{tabular}{ll}
\hline Cohort & UNIDIFF-parameter \\
Sons born 1955-64 & 1.00 \\
Sons born 1965-74 & 1.0756 \\
Daughters born 1955-64 & .8496
\end{tabular}

For the sons, the origin-destination association has become $7.56 \%$ (1.0756) stronger from the oldest to the youngest cohort. Sons born 1965-74 have therefore experienced a more rigid mobility structure at the top than their older brothers. For the daughters, the result is the opposite. Even if the basic mobility structure is the same, the association is $15 \%$ weaker, and the mobility $15 \%$ stronger, than among the sons belonging to the same birth cohort, and 22\% stronger than among the youngest sons.
As this indicates, the daughters are less inclined to follow in their fathers' footsteps. Furthermore, intergenerational social capital relations to other positions rely more strongly on father-daughter relations than on father-son relations. But this said, one should keep Beller's (2009) important critique of social mobility-research in mind: we know too little about mother-daughter mobility, but we do know that mothers matter. The relative mobility for women might therefore be exaggerated. 


\section{Barriers and Trajectories. Intergeneratio- nal Conversion Strategies}

In the sociology of elites and of social mobility, indications on what Parkin (1979) conceptualized as social closure, either structural or intentional, is seen as a key element in how resources are monopolized, and how privileges are transferred from one generation to the next. If the number of destination positions is limited, access to these positions becomes all the more important. The higher the intergenerational reproduction rate, the stronger is also the resource monopolization.

Similarly, family-dynastic networks are also good indicators on the potential for resource mobilization. While strong positioninternal networks can be both exclusive and excluding, networks to family members in other positions in top positions can have a multiplier effect on already existing capital types and volumes. From one generation to the next, it can also be a way of converting one form of capital to another. When the leading politician's son or daughter becomes a CEO, s/he not only converts political capital into economic capital; s/he also inherits the father's or mother's network. To be a member of a family dynasty can thus be a highly valuable form of inherited social capital. Also for that reason, the structure, the stability and the changes of these dynastic relations must be analyzed.

For as our analyses show, even in the Norwegian elites, some inheritors prove to be "more equal than others". To gain insight into how structural oppositions between top positions are reproduced, how the elites are internally polarized, how the monopolization of assets takes place, its consequences, and insight into how privileges are transferred from one generation to the next, is therefore a necessary undertaking in any sociological study of the elites and the upper classes.

Combining studies of the structuring of the Norwegian field of power (see HJELLBREKKE et al., 2007; DENORD et al., 2011) with studies of internal and intergenerational circulation at the top of the Norwegian educational and professional hierarchies, may thus not only serve as an example of how the gap between the sociology of social class and the sociology of elites can be bridged. It also makes it possible to address the recurring problem of how to simultaneously analyze social stability and social change, and to assess whether, or to what degree it is correct that: "plus ça change, plus c'est la même chose".

\section{References}

ABBOTT, A. The system of professions. An essay on the division of expert labour. Chicago: The University of Chicago Press, 1988.

ARON, R. Social structure and the ruling class: Part 1. The British Journal of Sociology. V. 1, p. 1-16, 1950a.

Social structure and the ruling class: Part 2. The British Journal of Sociology. V. 2, p. 126146, $1950 b$.

AUBERT, V. Norske jurister fra 1814 til den annen verdenskrig. («Norwegian law candidates from 1814 to WWII"). Oslo: Institutt for samfunnsforskning, 1960.

AUBERT, V., et. al. Akademikere i norsk samfunnsstruktur 1800-1950. (Academics in the Norwegian Societal Structure 1800-1950). Tidsskrift for samfunnsforskning. V.1, n. ${ }^{\circ}$ p. 185-204, 1960.

BELLER, E. Bringing Intergenerational Social Mobility Researchers Into the Twenty-First Century: Why Mothers Matter. American Sociological Review. N. ${ }^{\circ}$ 74, p. 507-528, 2009. 
BOURDIEU, P. The forms of capital. In: Richardson, J. G. (Org.). Handbook of Theory and Research for the Sociology of Education. New York: Greenwood Press: 1986, pp. 241-258.

The State Nobility. Cambridge: Polity Press, 1996.

BOURDIEU, P ; SAINT MARTIN, M. Le patronat. Actes de la recherche en sciences sociales. N. ${ }^{\circ}$ 20/21, p. 3-83, 1978.

BREEN, R. Social Mobility in Europe. Oxford: 0xford University Press, 2004.

CHRISTOPHERSEN, K. Den norske øvre serviceklassen og nedadgående social mobilitet (The Norwegian Upper Service Class and Downward Mobility). Master degree thesis. Bergen: Department of Sociology, 2011.

CORNWELL, B. Social Sequence Analysis: Methods and Applications. Cambridge: Cambridge University Press, 2015.

DENORD, F. et. al. Social capital in the field of power: The case of Norway. The Sociological Revie. V. 59, n. ${ }^{\circ} 1$, p. 86-108, 2011.

ERIKSON, R.; GOLDTHORPE, J. H. The Constant Flux. A Study of Class Mobility in Industrial Society. Oxford: Oxford University Press, 1992.

FEATHERMAN, D. L. et. al. Assumptions of Social Mobility Research in the US: The Case of Occupational Status. Social Science Research. V. 4, p. 329-60, 1975.

FIELD, G. L.; HIGLEY, J. Elitism. London: Routledge, 1980.

FLEMMEN, M. The Structure of the Upper Class: A Social Space Approach. Sociology. V. 46, p.10391058, 2012.

GRANOVETTER, M. Getting a job. A study of contacts and careers. Chicago: Chicago University Press, 1973.

GRUSKY, D.; WEEDEN, K. A. Decomposition Without Death: A Research Agenda for a New Class Analysis. Acta Sociologica. V. 44, n. ${ }^{\circ}$, p. 203-218, 2001.
GULBRANDSEN, T. et. al. Norske makteliter (Norwegian Power Elites). Oslo: Gyldendal Akademisk, 2002.

HANSEN, M. N. Utdanningspolitikk og ulikhet. Rekruttering til høyere utdanning 1985-1996. (Educational Policy and Inequality. Recruitment to Higher Education 1985-1996). Tidsskrift for samfunnsforskning. V. 42, n. ${ }^{\circ 2}$, p. 172-203,1999.

HANSEN, M. N. Sosial bakgrunn og karakterer blant juridiske kandidater. (Social Background and Grades Among Law Candidates.). Tidsskrift for samfunnsforskning. V. 41, n. ${ }^{\circ}$ 2, p. 151-185, 2000.

HANSEN, M. N. Education and Economic Rewards. Variations by Social Origins and Income Measures. European Sociological Review. V. 17, n. 3 , p. 209-231, 2001.

HARTMANN, M. The Sociology of Elites. London: Routledge, 2006.

HARTMANN, M. Eliten und Macht in Europa. Ein internationaler Vergleich. Frankfurt \&t New York: Campus Verlag, 2007.

HIGLEY, J. Elite Theory in Political Sociology. Paper presented at the IPSA-2008 conference, Montréal, 2008.

HJELLBREKKE, J. Multiple Correspondence Analysis for the Social Sciences. London: Routledge, 2018.

HJELLBREKKE, J.; KORSNES, 0. Sosial kapitalstrukturar i norske elitar. ("Social Capital Structures in Norwegian Elites"). Tidsskrift for samfunnsforskning. V. 46, p. 467-502, 2005.

Sosial mobilitet. (Social Mobility). Oslo: Det norske samlaget, 2012.

Intergenerasjonell mobilitet og sirkulasjon i norske elitar og profesjonar. (Intergenerational Mobility and Circulation. In: KORSNES, H.; HJELLBREKKE, J. (Orgs.). Elite og klasse i et egalitært samfunn. Oslo: Universitetsforlaget, 2014, pp. 54-76. 
Women in the field of power. Sociologica. Italian Journal of Sociology Online, Vol. 10, n. .2 , p. $1-28,2016$.

HJELLBREKKE, J. et. al. The Norwegian field of anno 2000. European Societies. V. 2, n. ${ }^{\circ}$ 9, p. 245-273, 2007.

JONSSON, J. O. et. al. Micro-Class Mobility. Social Reproduction in Four Countries. American Journal of Sociology. N.`114, p. 977-1036, 2009.

KOLABINSKA, M. La circulation des élites en France, étude historique depuis la fin du XIe siècle jusqu'à la grande Révolution. Lausanne: Imprimeurs réunies, 1912.

LINDBEKK, T. Den sosiale rekruttering til de akademiske profesjoner i vår tid. (The Social Recruitment to the Academic Professions in our Time) . Tidsskrift for samfunnsforskning. V. 3, n. ${ }^{\circ}$, p. 231-254, 1962.

LIPSET, S. M.; ZETTERBERG, H. L. A comparative study of social mobility, its causes and consequences. In: LIPSET, S.M.; BENDIX, R. (Orgs.). Social mobility in industrial society. Berkeley: University of California Press, 1956.

MANNSÅKER, D. Det norske presteskapet i det 19. hundreåret. (The Norwegian Clergy in the $19^{\text {th }}$ Century). Oslo: Det Norske Samlaget, 1954.

PARETO, V. The Rise and Fall of Elites. New Brunswick, NJ: Transaction Publishers, 2003.

The Mind and Society. New York: Harcourt, Brace \&t Co, 1935.

PARKIN, F. Marxism and Class Theory. A Bourgeois Critique. London: Tavistock Publications, 1979.

PIKETTY, T. Capital et idéologie. Paris: Le Seuil, 2019.

SCOTT, J. Stratification and Power. Structures of Class, Status and Command. Cambridge: Polity Press, 1996.

SEJERSTED, F. Demokratisk kapitalisme. (Democratic Capitalism). Oslo: Universitetsforlaget, 1991.
SOROKIN, P. A. Social and Cultural Mobility. Glencoe Ill.: Free Press, 1959.

. A. Social mobility. In: Edwin, R.A. (Org.). Encyclopaedia of the Social Sciences. V. X. New York: Macmillan, 1949, pp. 555-56.

TOFT, M. Upper class trajectories: capital specific pathways to power. Socio-Economic Review's special issue. V.16, n. ${ }^{\circ}$, p. 341-64, 2018 a.

Mobility closure in the upper class: assessing time and forms of Capital. British Journal of Sociology. doi: 10.1111/1468-4446.12362, 2018b.

TORGERSEN, U. Ledersjiktet innenfor næringslivet. Stabilitet eller fornyelse ? (The business managers. Stability or renewal?). Tidsskrift for samfunnsforskning. V. 4, n. ${ }^{\circ} 1$, p. 43-55, 1963.

VALLET, L. A. Quarante années de mobilité sociale en France. L'évolution de la fluidité sociale à la lumière de modèles récents. Revue française de sociologie. V. 40, n. ${ }^{\circ}$, p. 5-64, 1999.

VON EYE, A.; MUN, E-Y. Log-Linear Modelling. Concepts, Interpretation and Application. Hoboken, N.J.: John Wiley \& Sons, 2013.

WEBER, M. Economy and Society. Berkeley: University of California Press, 1978. 
RESUMO

Apesar dos apelos para suprir a lacuna entre a sociologia das classes sociais e a sociologia das elites, há poucos exemplos em que isso tenha sido feito. Este artigo busca fazer isso aplicando abordagens e técnicas estatísticas comumente utilizadas em estudos de mobilidade social em nas análise da mobilidade de circulação em formações de elite. Com base em dados de registro de toda a população norueguesa nascida entre 1955 e 1975, analisamos a mobilidade educacional e profissional intergeracional entre "os herdeiros bem-sucedidos". Desta forma, e focalizando as barreiras e as trajetórias de mobilidade, buscamos descobrir os padrões de estabilidade e de mudança nas relações dinásticas familiares, ou seja, relações que se baseiam principalmente em formas hereditárias de capital. Além disso, esses padrões podem revelar quais formas de conversão intergeracional de capital têm sido as mais comuns e, portanto, também, as mais aceitáveis nas classes média-alta e na classe alta da Noruega do pós-guerra, e quais conversões têm sido menos comuns. Os resultados indicam que, mesmo nas elites norueguesas supostamente igualitárias, alguns herdeiros provam ser "mais iguais do que outros".

PALAVRAS-CHAVE: Elites. Conversão intergeracional de capital. Mobilidade. Circulação no topo.

\section{ABSTRACT}

Despite calls for bridging the gap between the sociology of social class and the sociology of elites, there are few examples where this actually has been done. This article seeks to do so by applying approaches and statistical techniques commonly used in studies of social mobility in an analysis of circulation mobility in elite formations. Based on register data on the whole Norwegian population born 1955-1975, we analyze the educational and professional intergenerational mobility among "the successful inheritors". In this way, and by focusing on mobility barriers and trajectories, we seek to uncover patterns of stability and change in family dynastic relations, i.e. relations that primarily are based on inherited forms of capital. These patterns can also reveal what forms of intergenerational capital conversion have been the most common, and therefore also the most acceptable, in the upper and upper middle classes in postwar Norway, and what conversions have been less common. The results indicate that even in the supposedly egalitarian Norwegian elites, some inheritors prove to be "more equal than others".

KEY-WORDS: Elite. Intergerational capital conversion. Mobility. Circulation an the top.

Recebido em: 01/07/2019

Aprovado em: 26/11/2019 